\title{
Environment, regulation and the moral economy of food in the Slow Food movement
}

\author{
Valeria Siniscalchi ${ }^{1}$ \\ École des Hautes Études en Sciences Sociales, France
}

\section{A political ethnography of Slow Food}

The emergence of new forms of capitalism has been accompanied by problems of resource distribution and an endangered natural environment. This has highlighted the necessity of defining a 'sustainable' economy. A variety of social and increasingly transnational movements (from peasants and consumers to anti-GMO) have emerged, with different kinds of political engagement. ${ }^{2}$ They seek to elaborate new forms of economy and create new sites of political action. Analysis of such movements draws attention to their rhetoric, to the specific images they produce of the environment but also, as Koensler and Papa point out, to the important dimension of power relations, shifting "attention towards practices and agency." (Koensler and Papa 2013: 287).

Founded in Northern Italy in the mid 1980s, Slow Food has become an international movement in less than twenty five years, assembling nearly 100,000 members in different countries around the world. Since its birth, it has presented itself as an association that defends quality food consumption that respects 'human rhythms' and pleasure. Over the years, attention paid to gastronomy has become more complex. Slow Food has changed its public image and internal functioning, and conceived new modes of action. First, it has extended its focus to the environment under the banner of 'eco-gastronomy', and secondly it expanded from consumers to producers. Today it presents itself as the only movement capable of intervening in the entire food chain. Its new battlefronts include the fight against intensive agro-industrial production, against standardization of taste and food, against GMOs, against nuclear power and non-renewable energy, and against the privatisation of water. These are linked to, and reflected in, significant changes in Slow Food philosophy.

My research on Slow Food began at the end of 2006 with participant-observation and interviews in the Salone del gusto (Hall of Taste) and Terra Madre (Mother Earth), two of the many international events organized by the movement. I then pursued my research in France, where I followed the evolution of Slow Food's French National Association and the activities of some of its local chapters (convivia). From 2009 to 2012, my fieldwork took me to the city of Bra where the movement's headquarters are located. Here, I studied the association's functioning and its economic and political stakes. Simultaneously, I followed Slow Food's activities and international connections, particularly with France. As distinct from other studies on Slow Food, my ethnographic work was conducted backstage and in the wings of the association. ${ }^{3}$ Over three years, I conducted repeated interviews with the personnel working in the association or holding political responsibilities (around 160 employees in Bra itself) as well as in other Italian regions and in some other European countries. I met people close to the association (including the producers) or others who had taken some distance from the movement. This formed only part of my fieldwork. A substantial portion consisted of long term participant observation: of political bodies, of informal meetings, of the leaders' missions in Italy and abroad, and of international events and meetings. My research position, within the historical hub of the movement and its decision-making sites, enabled me to follow the daily life of its employees and its leaders. I was witness to the genesis of certain projects, observed the internal dynamics, conflicts and modes of management of power as well as the contradictions and ways in which they are lived and integrated at different levels.

\footnotetext{
${ }^{1}$ Maître de conférences, École des Hautes Études en Sciences Sociales, France, member of the Research Center Norbert Elias, 2 rue de la Charité 13002, Marseille, France. Email: valeria.siniscalchi "at" ehess.fr. Thanks to friends of Slow Food who accepted me in the corridors of the headquarters of the movement and put up with my presence over these last three years with great patience and affection. The time spent with them was always a rich experience for me, both from the human and intellectual point of view. Thanks to Arundhati Virmani for the translation of this article from French and for her analytical viewpoints. Thanks to Carole Counihan for her suggestions and wise advice, and two anonymous referees and the editors. The research was financed by the EHESS Research Funds, by the visiting professor program of the University of Cagliari and by the project "Patrimonialización y redefinición de la ruralidad. Nuevos usos del patrimonio local" (Universitat de Barcelona). This paper is in Koensler A. and Papa C. (eds.) "After anthropocentrism? Environmental conflicts, social movements and power," special section of the Journal of Political Ecology 20: 255-341.

${ }^{2}$ See Nash (2005) for an analysis of social movements.

${ }^{3}$ For other analyses of Slow Food, see Leitch (2003, 2009), Sassatelli and Davolio (2009), Murdoch and Miele (2004) and Parkins and Craig (2006).
} 
Most of the research on Slow Food observes the movement from its periphery, often critically, but without understanding the complexity of the internal dynamics; or from internally and often apologetically. Others researchers analyze its philosophy, public image, and rhetoric; this perspective makes sense for a movement that dedicates a lot of energy to communication. ${ }^{4}$ In my analysis of Slow Food, I try to account for the complexity of the movement, its contradictions, and its tensions, but also the political issues, avoiding the two extremes--uncritical apology or excessive criticism based on clichés and limited knowledge. Slow Food is a complex subject with several angles: it is an association with dues-paying members, but at the same time, it is a social and political movement supported by thousands all over the world. In some regards, if we consider some of its components, it is a private enterprise, particularly the department that organizes events and fairs. At the same time, it is similar to an NGO if we consider its projects in the Southern countries of the world. Its functioning has remained militant in some respects: its modes of action are based largely on voluntary work, with relatively modest salary levels of employees and directors in comparison to the private sector. Slow Food is an organization that is capable of putting on big events and negotiating and rubbing shoulders with a large spectrum of widely divergent political powers. In 2004, it founded a private university where students mainly from the USA, Latin America, Asia, and Europe, study the Gastronomic Sciences. Finally Slow Food is an actor in the national and international political field of decisions concerning food, but it is also a legitimate actor in spaces of political and social contestation, as I will show further on.

These diverse aspects must to be considered together. They account for the various forms of loyalty or opposition that Slow Food generates. They explain the heterogeneity and different levels of commitment among members who range from gourmets to producers, from the wine and food lovers to the militants. These different spirits are responsible for the variations of the movement in regions and in countries where it is represented, as well as for tensions within Slow Food. All these aspects appear to signal deep contradictions but in reality they are complementary, and constitute the movement today. ${ }^{5}$ This article aims to reflect upon the process that has made Slow Food a social and political movement involved with environmental issues and from there upon the imbrications between environment, economy and legality. More particularly, my analysis will deal with process of labeling and valorization of small, endangered, high quality products. These products, defined as presidia, are considered instruments to protect the natural environment, but they are also instruments to create new economic and political spaces. Moreover, through presidia Slow Food becomes an actor in the conflictual process of the process of regulating food production.

\section{Defending the environment through food}

If the point of departure of the association was good wine and good food, the environment, which is currently one of the characteristic issues with Slow Food, became a fundamental matter of interest to the movement's leaders at the end of the 1990s. First, some of the attention shifted from products and modes of production to include the environmental aspect through the 'Ark of taste' (Arca del gusto) and the 'Prize for biodiversity' (Premio della biodiversità). The Ark of taste is an inventory of products that merit attention. It was conceived as an instrument "to save the planet of flavors (...) from the flood of industrial uniformity" (from the Manifesto dell'Arca del gusto; Slow Food 1997). ${ }^{6}$ Biodiversity has been integrated into the association's actions with a language that blends biblical images and military terms that can also be found in other more radical ecological movements, but in Slow Food these terms are also used in an ironic sense, at least in the early days. The 'Prize for biodiversity' lasted only a few years and was then replaced by the presidia projects analyzed below, intended to identify and reward producers whose activities contribute to maintaining the planet's agro-alimentary diversity in the fields of agriculture, livestock rearing and gastronomy. Finally, in 2003 the non-profit 'Slow Food Foundation for biodiversity' was created. It aimed to gather funds and invest them in defence of biodiversity, essentially in the Southern countries in support of their local food production networks.

The movement's philosophy accompanied these changes. Since the publication of founder and leader Carlo Petrini's book, Buono, pulito e giusto (2005), the triad 'Good, Clean and Fair' has become the movement's slogan and rallying cry. It signals the evolution of the philosophy along with its formalization. 'Good' refers to taste and quality of food products. 'Clean' shifts attention to the place and manner of production and hence to the environment: 'clean' indicates products that respect the environment or techniques of production and forms of distribution that reduce or eliminate chemicals and environmental damage. Finally, the notion 'fair' refers to social justice for producers. Production, distribution and consumption are fair when they respect the rights and dignity of producers, and defend fair wages and working conditions. In certain respects, this discourse is close to the rhetoric of Fair Trade but it integrates power relations and consumer power into the discussion, in order to give a fair place to producers, not only from the South but also from Europe. ${ }^{7}$ Indirectly, local and artisanal production is valued and considered as

\footnotetext{
${ }^{4}$ Sassatelli and Davolio (2009) offer a relevant analysis of the texts and the accounts of some of the movement's leaders.

${ }^{5}$ I'm working on a book on these themes.

${ }^{6}$ See http://www.fondazioneslowfood.it/filemanager/arca/manifesto.pdf (accessed 5/2013)

${ }^{7}$ On Fair Trade Movement see among others Grimes (2005) and Luetchford (2008).
} 
the only means to preserve the diversity of products, their taste and even the environment. This shift and 'integration', increasingly visible, of farmers and small livestock breeders in the movement is also expressed through large Slow Food events: besides the Salone del Gusto, Terra Madre, inaugurated in 2004 is held every two years, bringing together small producers from all over the world to discuss food problems and politics, the future of local economies, and sustainable production.

The triad of 'Good, Clean and Fair' can be also read chronologically: the three words correspond to the movement's evolution and its philosophies during these last fifteen years. Its first concern was 'Good', and consequently it adopted the consumer's viewpoint. A shift in attention to products was clearly affirmed with the institution of the Prize for biodiversity and the first projects of presidia. The next step included the environmental context and modes of production. Finally, with projects around small producers and local economies and the Terra Madre meeting, Slow Food's gaze and its actions 'encompassed' producers in their living and working conditions. The three terms 'Good, Clean and Fair' delimit new political spaces of action which include both producers and the environment. Which environment are they talking about? The environment targeted by Slow Food actions includes agricultural activities as well as a 'food' dimension. This is one of Slow Food's specificities compared to other ecological movements. The environment is a collective good and at the same time it is linked to individual, private ways of producing food. ${ }^{8}$

Analyzing the notion of biodiversity, the President of the 'Slow Food Foundation for biodiversity' explained to me;

When we started action in the field, the figure of the gourmet, though a visionary, was limited to what arrived in his plate. When we went to see what occurred "before" the food arrived in the plate, what was there in the fields, in the production centres, we began to think about biodiversity. That was our big challenge, namely, affirming that biodiversity does not consist only of forests, pandas, eagles or tigers but also of sausages produced by man, of species and cultivated varieties, domesticated over 10,000 years of agriculture (...). All this is biodiversity: it has the same environmental and landscape values of spontaneous biodiversity. In fact, it is thanks to us that the agri-food world was integrated in the concept of biodiversity: it is to our credit. (P.S. 18/6/2009)

These statements intersect with those of other associations and movements but also with some scientific positions (Adam 1998; Hirsh 2005). Nonetheless, at the end of the 1990s they were original in the Italian context. ${ }^{9}$ Biodiversity is conceived above all as nutritive and gastronomic biodiversity. And Slow Food's concept of the environment includes not just fields, pastures and vineyards, but also the production knowledge and techniques. Slow Food's vocabulary also changed. 'Eco-gastronomy' expressed the attempt to reconcile interests of gastronomy and ecology, often perceived as antagonistic. Slow Food defines consumers as 'co-producers', which recalls the term 'consumer actor' (consom'acteur) used in AMAP networks in France. ${ }^{10}$ But it goes far beyond that since it places the consumer on the obverse side of the relationship, alongside the producer. The co-producer is a performative term: Slow Food members are encouraged to engage themselves alongside the producers, who are recognized and considered increasingly central to the movement's interests. Yet, the term 'co-producer' is not sufficient to describe goals and practices. Here lies one of the contradictions of the movement expressed through its different styles of membership.

Terra Madre has developed another term, 'food community', to refer to all those people who take part in the production and distribution of a food in a defined geographical area. Initially difficult to define, it has been increasingly integrated in members' vocabulary and actions. The accent on the social dimension of food draws attention to the different actors of local economies. This too is a performative term that describes and aims at creating "communities" of goals woven around productive activities and 'imagined' economies (Anderson 1996). These, in their turn, are directly connected to an ideal past, at a safe distance from the 'ills' of the present. As Nash emphasizes, some values such as human rights, environmental conservation, social justice "provide an ever-changing frame of reference that animate social movements and serve to validate the changes they institute or the revitalisation of an imagined past without conflict" (Nash 2005: 13). 'Peasants' and small producers of the global South and of the North are considered as a lever for a slow but possible transformation of the world. The more utopian dimension of Slow Food's message - that aims at bringing the

\footnotetext{
${ }^{8}$ These features recall the notion of pleasure, one of the pillars of the movement. In the 1980s, Slow Food emphasized the pleasure of eating and drinking in the private sphere as well as giving it a collective value in its philosophy. I explore these topics more widely in Siniscalchi (2013). See Piermattei (2013) on the opposition between a global concept of environment and a private one.

${ }^{9}$ The same holds true for the notion of 'slowness', today claimed by other organizations, associations or a variety of professionals but who share a refusal of productive logic and waste, attention to environment, respect of human rhythms and seasons and moderation enumerated in various forms.

${ }^{10}$ Association pour le maintien de l'agriculture paysanne, close to Community Supported Agriculture. Cf. Lamine (2008).
} 
poles of the food chain closer, connecting all the actors of local economies in different parts of the world to try and change the food system - is difficult to achieve. The connection between producers and consumers does not take place everywhere in the same way or with the same intensity and the reality of the movement is not always coherent with its philosophy. I will came back to this later. Anyway, in this framework, the presidia project is one of the most concrete actions of the movement.

\section{Presidia: traditional products and environment}

The presidia project is one of the spaces of action in the field of biodiversity that best illustrates how Slow Food's political and economic involvement with environmental questions took shape. The first presidia projects emerged at the end of the 1990s. Today, there are more than 200 presidia in Italy and around 160 elsewhere, and these numbers seem destined to grow, as the leaders of the movement declare at each public occasion.

Observing the wide range of projects initiated by Slow Food over time, or others in which it is involved: some are abandoned after some years, others begun, and still others transformed. Although some people working in the presidia project describe it as 'old', Slow Food still continues to invest in it through its actions. "Presidia projects remain vital for many producers. Indeed, presidia have been a means of setting in motion an extremely important mechanism", declared the head of the Italian presidia office (R.P. 29/10/2009). If the 'Prize for biodiversity' constituted a reward for virtuous producers, presidia are more complex, and conceived to have a long-term impact. The down-to-earth approach characterized by direct interventions in the world of production is surely one of the explanations for their lasting presence, but it would be simplistic to see them merely in this light. Presidia are not simply labelling processes. Through presidia, Slow Food aims to protect and promote "high quality" endangered products and "enter the practical world of production, get to know local places, meet producers and promote their products and knowledge" (Battaglino, Giannini and Milano 2010: 11). In this sense, the presidia constitute an economic and political project;

While the environmental aspect is clearly vital, and in some cases is the focus of the Presidium, the economic, social and cultural aspects are also crucial. For example, Presidia products are often disappearing because they are no longer profitable and producers need guarantees about their economic viability in order to continue their activity. (Battaglino, Ceriani, Giannini, Milano 2012: 22) ${ }^{11}$

Through a presidium Slow Food selects a product, being attentive to local varieties but also to the area of production and to an ecosystem. "Slow Food Presidia preserve traditional knowledge, protect territory and save biodiversity", explains one of the brochures of the presidia project. The director of the Italian presidia office told me;

Environmental goals are part of each Presidium. Each (Slow Food) product specification asks producers to eliminate or reduce chemical treatment, ensure animals' well-being, safeguard local races and native varieties whenever possible and privilege the use of renewable energies. (R.P. 23/11/2010)

Alongside these environmental objectives, there are "cultural" goals, "strengthening producers' cultural identity and promoting production areas." (Battaglino, Ceriani, Giannini, Milano 2012: 22). These social and cultural aspects bring the presidia closer to production processes located in the field of "typicity". ${ }^{12}$ Typicity is defined by a specific relationship of a project or object to space and time. In order to become presidia, products must possess a 'history'. Being endowed with a history, in the case of a food product, refers to recurring practices and knowledge over time. This repetition and reproduction in time thus guarantees a product's typicity. At the same time, typicity is also defined through a link with a given, demarcated space: products must be linked to a geographic and cultural area (in French, terroir) as well as to a social group. Knowledge and practices are reproduced over time but also in geographical and administrative space -- and above all in a social space in which production occurs.

Conversely, the process of 'typicization' (that is to say, transformation of products into typical

\footnotetext{
${ }^{11}$ These products have no more market relevance because their production has become too marginal or because there are very few producers.

${ }^{12}$ Literature on 'typical' production is abundant and these questions are treated from very different angles: studies of material culture interested in techniques, knowledge and their transmission; works inspired by The social life of things (Appadurai 1988) seeking to reconstruct the social biography of objects and products, their trajectories and the modes of fixing their value; and work questioning the relations between the local and the global through trajectories of products or tourist performances.
} 
products), which also characterizes presidia, contributes to creating or consolidating the history of a region and its inhabitants. ${ }^{13}$ In this sense, presidia serve as labels for local actors, signifying the existence of a territory and the specific knowledge of its inhabitants. Presidia can also contribute to renaming this territory of production. Thus, Slow Food becomes an actor in the process of (re)defining and imagining places that characterizes the field of 'typicity'. ${ }^{14}$ Presidia also embody Slow Food battles against the industrialization of food. The production of limited quantities by small artisans or by small agricultural farms according to 'traditional' techniques, and their inclusion in a narrow list of products selected by Slow Food, are elements that make presidia unique products and help to valorize them. Typicity and artisanship constitute added values for goods, allowing an increase in market price or simply, as in the case of many presidia, ensuring their presence on the market. ${ }^{15}$ Therefore presidia are located in a regime of singularity. They are defined by a 'constellation' of qualities and frequently, from the point of view of quantity their production is closer to a limited series rather than to goods produced on an industrial scale (cf. Karpik 2007).

\section{Presidia and new normative systems}

If presidia are "traditional" products with a past, they are only partially constructed by projecting them from the present into the past. They are conceived as projects for the future: they are considered as social connectors and instruments of future economic development.

My hypothesis is that presidia play the role both of a prototype and a paradigm. They are examples to follow and models of action. They are worthy examples not only for other actors of the same productive network but more generally, for food producers and stock-breeders who share the desire to change the modes of production and the rules of food distribution. In this sense, presidia are not simply one of the many fields of action for Slow Food but a means to transform the movement's philosophy into something concrete. As engines of development and models to be reproduced, they have also become an instrument for Slow Food's political battles. For example, Slow Food supports legalizing production of non-pasteurized cheese through presidia in countries including Canada and Ireland. The presidium of Irish Raw Milk Cheese was presented as a tool of rebellion against norms that threatened to eliminate this mode of production and therefore its products, since it had become illegal.

"This presidium aims at changing the attitude of Dublin legislators" said a producer, after six legal trials that finally recognized his rights;

Unlike many other presidia, which focus on a specific product, this project includes different types of cheese produced in the entire Irish territory. The presidium is formed of eight cheese producing units working with a variety of styles and techniques but with the common goal of producing high quality cheese by using non pasteurized milk sourced from their own herds. (Presidia, Slow Food Foundation for Biodiversity, 2008).

The Irish project, more than others, is clearly presented as a political project that aims to change a normative system;

The presidium is represented by a series of cheese dairies considered as ambassadors of Irish cheese production (to) encourage all non pasteurized cheese producers of Ireland in promoting consumption of these cheeses (...). This project aims to raise awareness of the qualities of these cheeses among consumers, retailers and food policy experts. (Presidia, Slow Food Foundation for Biodiversity, 2008)

This symbolic battle recalls others in which Slow Food played a different role: for example, the struggle to ease European rules such as HACCP (Hazard Analysis Control Critical Point), accepted by Italian legislation on food safety, but considered unsuitable by Slow Food for small artisanal activities. But it also recalls other more recent battles, such as Slow Food participation in California in 2012 in campaigns to modify the ruling on labelling products containing GMO (Genetically Modified Organism) ingredients. All these battles to change norms are also struggles to establish new normative systems and new legalities. I consider the affirmation of new legalities as forms of political commitment and one of the most important

\footnotetext{
${ }^{13}$ On the question of the relationship between singularity and repetition see Siniscalchi (2010).

${ }^{14}$ Among others, see Ulin (1995, 1996) on Southwest French wine, Terrio (2000) on French Chocolate, Meneley (2007) on extra virgin olive oil, and Paxsons (2010) on artisan cheese. On processes of 'localisation', see Abram and Waldren (1997), Appadurai (1998), Gupta and Ferguson (1999), Low and Lawrence-Zùniga (2003).

${ }^{15}$ The problem of the price is crucial in presidia projects. The price of food has a political dimension: it must be fair for producers who must be able to make a living from their production. At the same time, if the project has economic goals for producers, the prices of some presidia do not make them accessible to everyone. The price singularizes products: it says that the quality has a cost.
} 
aspects of Slow Food presidia at a broader level.

Presidia projects are based upon (or often anticipate) very strict production protocols. They define breeds, species, areas, times and techniques of production, ultimately even seasons and places (for example, high mountain pastures) with great precision. The protocols set up rules that producers must respect if they wish to remain in Slow Food's field of action and benefit from its promotion initiatives. Through these production protocols, Slow Food acts as a regulatory body: it fixes the limits of the area of production but equally lays down limits on the quantity produced; it establishes the rules and the techniques of production. In the presidia office, people remember the first specifications drawn up when the project began. Some of them were too narrow and did not take into account the reality of animal farming. Over time, people inside Slow Food honed their knowledge of the world of production and became legitimate mediators for many producers.

In most cases, these rules occupy 'empty' spaces: presidia are often products that have no other labels or designations because their production and economic relevance is very small. Here, Slow Food seems to play the role of an institute of certification though distinguishing itself not only by its method but also by the principles that govern this kind of labelling. Product specifications are drawn up in a large number of cases in consultation with producers, during visits to sites of production and in meetings that precede the institution of a presidium. The protocol is thus produced after long negotiations and several interventions. This does not imply that there is no power struggle or no conflicts between producers themselves or between producers and Slow Food. But Slow Food refuses to assume the role of a controlling body and insists that producers exercise this control amongst themselves, for example, over the quantity of presidia products produced. An important element for Italian presidia is that since 2009, producers may use a specific label, 'Presidio Slow Food.' The use of this logo is subject to payment of an annual fee, fixed on the basis of a complicated calculation that takes account several variables, including the quantity of presidia produced. The entire normative record and the relationship between Slow Food and the producers that adhere to a presidium, and between Slow Food and the consumers, is understood by the people involved as an outcome of trust. It is displayed and shown as a value that allows the construction of these new normative systems and spaces of legality.

\section{Presidia: power conflicts}

Presidia, conceived as unique products of high quality, can be considered in some respects to be prototypes that define the paradigm of the very essential - that which must be preserved in the broad field of food production. The prototype fixes limits, defines form, and confirms the content of the object singled out for reproduction and value through the label of presidia. Protocols define the range of micro-possibilities of variation that characterize 'typical' products, that are never reproduced identically. Repetition inserts products in the process of change and the prototype delimits change as well as inscribing the margins of possible variation. The uniqueness and authenticity of presidia products is determined by their adherence to this model. But the defining paradigm is always the result of negotiations involving different actors. Presidia, like any other 'typical' product, are also the result of more or less explicit power struggles. The modes of expressing tensions and rhetoric are different from other fields in which food is more explicitly at the heart of conflicts, for example the debates over GMO maize (Fitting 2011).

In some cases, Slow Food presidia rules intervene in spaces already 'occupied' by European norms. For example, Italian products that already come under PDO (Protected Designation of Origin, cf. 1992 European regulation $n^{\circ}$ 2081) may seek to distinguish themselves from a designation seen as too generic by entering the presidia project. In these cases, the presidium identifies a small area of production, or preparation and cultivation techniques, or even a particular species inside a Protected Designation of Origin. Slow Food's political struggle in this case is linked to the producers' battles as, for example, in the case of Sardinian Fiore Sardo cheese. ${ }^{16}$ The Sardinian producers are also shepherds and they are fighting against industrial producers who invade the local market with a cheaper cheese produced with pasteurized milk, often originating in other European countries. But their battle is also against institutions that have elaborated norms that do not protect the small producers, do not give them visibility, and prevent them from occupying a place in a real competitive market. In this case presidia producers are not situated outside the market or market logics: they aim to modify these logics from inside, and improve the status of the Sardinian product. The presidia project seems to them to be one of the possible ways to do this.

The norms that Slow Food elaborates, and which are evoked through the 'Slow Food Presidium' label, are superimposed on those fixed by the Italian Ministry of Agricultural Policy which applies European regulations. Slow Food norms are often stricter than the latter. As a result, the Ministry can perceive Slow Food as an alternative, one symbolically opposed to the State. This opposition produces concrete effects: in some cases the Ministry has imposed sanctions on producers who choose to use both labeling systems. If both labels are on the product, the Ministry refuses to accept this because it implicitly reduces PDO's value by juxtaposing the two normative systems. The Ministry tries to fight against organisations like Slow Food

\footnotetext{
${ }^{16}$ For an analysis of others controversies concerning cheese, see Corti (2011) on Bitto Cheese.
} 
that are acting in much the same manner as the State, in the same fields, and moreover, applying stricter regulation. The possibility that Slow Food produces another form of regulation is not accepted; it is declared to be opposing and weakening State regulation. ${ }^{17}$

Slow Food appears as an intermediate regulatory body, operating between the State and the selfregulation of producers. Slow Food proposes new normative models, for example its regulation of raw milk. This intermediary role is not neutral: it produce specific frictions and tensions. Alliances, power dynamics, and interests mark the life of the presidia, hidden behind seemingly consensual relationships. It is crucial to analyze these political dynamics, paying attention to their processual dimension. ${ }^{18}$

In Italy, if seen in the long term, the number of presidia have remained relatively constant. New ones are founded each year whilst others are declassified for various reasons. Sometimes, the production levels are very marginal and notwithstanding Slow Food's intervention, do not taken off in terms of financial viability. In some instances it could be that the product did not manage to move beyond the scale of family production.

In other cases, products have become well known, production has greatly increased in quantity and Slow Food's intervention is no longer considered necessary. In still other cases, conflicts between producers who have not managed to work together have drained the presidium of its 'social' meaning, which are considered necessary from the point of view of people working on presidia projects. Conflicts also erupt between Slow Food and producers because relationships of trust are lacking or because the price that producers apply becomes too high from the Slow Food point of view.

Sometimes tensions reach boiling point. Slow Food sees the payments it demands from producers for using the presidia logo (from $50 €$ to $1000 €$ for the most part) as a compensation for benefitting from the movement's name, capitalizing on its notoriety, and as a contribution to costs and time invested. Some producers disagree over the amounts to be paid, and consider Slow Food to be an economic machine that demands money. Furthermore, from the point of view of those who work in presidia offices, the royalties are not enough to pay the office costs. Conflicts also break out because other actors with diverging interests try to appropriate a project by draining it of its political meaning, for example using it only for its economic advantages.

In some cases friction appears simply because Slow Food is too far removed from the material demands of local producers and fails to understand the specific local dynamics. Therefore, Slow Food presidia must be understood as a process: they are the result of unstable political and social agreements; they have an origin and can also have an end. They must be understood as a combination of political, economic and normative characteristics. They are political, flexible, but also strategic - but not always in step with all local contexts. In this sense and at the same time, presidia allow Slow Food to have a presence around the world as well as in regions and countries where the movement is weaker. They contribute to consolidating Slow Food's image and political legitimacy and, in a certain sense, the producers who adhere to the project are its indirect participants.

\section{Eating, tasting, labeling}

Right from the beginning of Slow Food, taste education emerged as a collective activity and a means of teaching the association's principles to new members and sympathizers and training them. The taste laboratories are one of the key moments in the diffusion of Slow Food ideas. They are equally a sort of initiation for members and for people approaching Slow Food for the first time. Tasting is a means of creating conviviality and sharing a feeling of common membership of the association. Over the years, education in taste has become a central and strategic element, an instrument for safeguarding products and species. Tasting plays a role in three ways in the process of creation and maintenance of presidia. Taste is the most important step that permits products to became presidia in the first instance. Secondly, taste is a way to educate consumers, educators, local chapter (convivia) leaders and those in charge of local presidia. Thirdly, taste becomes a political and economic instrument.

How does the notion of a subjective palate - valued in the notion of 'good' - and the recognition of its cultural dimensions fit in with processes of selecting products that will become 'Slow Food presidia'? The process of becoming a presidia varies by country. But everywhere the decision to start a presidia project involves a mixture of economic, political, and social interests. In many cases, the local leaders of the association are at the centre of the process; in others cases the headquarters of the association play the most important role. Staff in the Slow Food Foundation for biodiversity always visit producers, taste products (in the place of production and in Slow Food offices) and they describe, choose and select. In this phase, tasting

\footnotetext{
${ }_{17}$ These regulations may be considered as a kind of soft law. On soft law, see Zerilli's analysis; "Soft law is typically embodied within non-binding legal instruments such as recommendations or declarations, but also "resolutions", "code of conduct", "guidelines" (2010: 9). And "soft law should (...) rather be explored as an object, an apparatus, in Foucauldian terminology un dispositif, namely a political technology which creates, enhances, maintains, perverts and modifies the exercise of power within a given social body." (Zerilli 2010: 11)

${ }^{18}$ Food and food products in general are political objects, objects of negotiation, conflicts and debates. Lien and Nerlich (2004) emphasize that food policies run transversal to 'classic' political spaces.
} 
is more than a uni-directional action: it is an interactive moment in the process of negotiation between those in charge at the local, national or international level, and producers. These interactions through taste are a means of negotiating the techniques of production, the quantity, the place, the ingredients but also a means of negotiating taste itself. Sometimes, the producers' points of view clash with the opinion of experts and officials in Slow Food offices. Slow Food staff try to learn to appreciate tastes that are different from the flavors they are familiar with, and at the same time they may ask for changes in the production process or exclude some producers from the perimeter of the presidia. Tasting is a way of selecting and transforming products into presidia. But tasting is also a way of reconfirming the presidia status. Some products for example may lose this status, as occurred recently with Sardinian casizzolu cheese - through tasting it was decided that producers had strayed too far from Slow Food principles.

Taste is also a way of training Slow Food educators. In a three day training program organized by Slow Food for convivia leaders and people in charge of local presidia in February 2011, one of the exercises included a comparative blind tasting. The President of the Slow Food Foundation for biodiversity asked participants to taste three cheeses (the same exercise was repeated with three apples, three jams...). Later they heard the history of each item (one was a Presidium, another was a 'good' product and the third was an industrial product) and taste again. After this second tasting, they had to identify the best amongst them from the Slow Food point of view. These collective exercises functioned equally as a sort of collective control: you can make mistakes but you cannot say that the industrial product is the presidium. A new element was formally introduced in this kind of tasting: the narrative, the history. "Blind tasting is no longer sufficient; we have to listen to narratives, to understand", said the President of Slow Food Foundation; "the products characteristic features need to be explained." (P. S. 19/2/11)

Finally, taste has become a political and economic instrument, an instrument for political battles. Individual and collective practices of taste are used in Slow Food's actions and politics to counteract market logic. Palate and taste become a means of diffusing the movement's philosophy but also they are tools for contesting market trends. ${ }^{19}$ For example, Fiore sardo cheese is considered far stronger than the average standard taste appreciated by average consumers and this marginalize it or excludes it from some markets. Slow Food's political action is, above all, translated as investment in the promotion of these products so as to increase their visibility through leaflets, fairs and various taste laboratories and training programmes offered to members. In this case, through a Presidium, Slow Food's defence of a product supports a certain taste , as well as playing the role of the promoter of a new kind of goodness. In the eyes of the movement's leaders, this is the right way not only to draw consumers closer to the producers but also to integrate them in the association and transform Slow Food's image, which remains largely that of a closed group of people who do not have financial problems and spend their time enjoying culinary delights.

Tasting is one of the activities that allows the association to talk about itself and to display the new themes at the heart of its philosophy. In this sense, 'taste laboratories' or 'taste exercise' may be read also as rituals in which food becomes a connection, a means of communication producing different forms of sociability, linking producers and consumers to specific physical and knowledge environments but also imagining new kinds of economy.

\section{Market and utopia, the ideal dimension and concrete economic action}

The presidia project constitutes a positive model from which inspiration should be drawn, but they are also spaces where new normative systems are elaborated. Today, they are conceived as an instrument for encouraging certain producers to legalize their sometimes 'undeclared or hidden' activities, since production is often really small in quantity. Actions around presidia can thus be read as one face of a coin: the other side is participation in other national or international battles that explicitly concern environment, legality, resources and common goods. Increasingly, Slow Food is becoming a political movement, taking a position in national political battles such as those opposing GMOs, the privatization of water, or even the return of nuclear power in Italy. The insertion of environment in Slow Food's list of interests, its defence of biodiversity and local economies, as well as social justice for producers, accompany an anti-mafia struggle and a larger anti-illegality battle. The association is concerning itself with transnational legality issues, rather than just the national or European Union (supranational) issues of food quality and regulation.

Slow Food's involvement in environmental activism expressed through presidia is also an engagement with a new kind of economic development. In this perspective, presidia activated in European countries do not have the same status as those created in the South, and the idea of economic development is not the same;

\footnotetext{
${ }^{19}$ Today the 'taste laboratories' have changed their focal point: wines are not simply savoured, but organizers try to place them in their production context. Products felt to be threatened are very present but the issue of 'local production' is also emphasized.
} 
There is a shift of meaning between the South and the North. In the Southern world, where there are interesting products, our goal is to activate Presidia, to create commercial outlets, revive producers' confidence, show them the importance of their work, reactivate local networks, places hopes in a network (...). In the Northern world the symbolic and cultural value prevails: Presidia allow us to send strong signals on the theme of domestic biodiversity, in order to guarantee gastronomic excellence vis-à-vis an agriculture that is becoming increasingly quantitative. (P.S. 13/9/2009)

In the South, these projects allow Slow Food to highlight the interest in small farmers and peasants, to build legitimacy (at the local and international level) and equally to publicize the movement more widely in terms of its ideas and membership.

In this framework, the three terms 'Good, Clean and Fair' work well together for Slow Food, because they make it possible to sketch the features of a new political commitment, to imagine forms of economy where peasant and artisanal producers would occupy an increasingly central place, and delimit new normative and political spaces of action which must include both producers and the natural environment.

The movement is also moving beyond, and challenging, the language associated with sustainable development and its measurability. 'Clean', for example, does not necessarily imply 'organic' (therefore it is not measurable by criteria that give organic certifications, such as AB). ${ }^{20}$ Justice envisaged as 'fair' is a universal notion, close to conceptions of universal human rights, and 'Good' also has a clear moral value. For Slow Food, 'Good, Clean and Fair' are parameters of a 'moral economy', that is to say, partly an alternative to liberalism, and partly, to a certain extent, a reform agenda. Slow Food leaders do not reject the world economy. On the contrary, they act within and through it (Leitch 2009). "The moral economy is one which creates value by respecting the environment and men", Carlo Petrini often declares . Here the notion of 'moral economy' is transformed by Slow Food leaders into a political goal. In this sense 'moral' synthesizes 'good, clean and fair'.

The 'moral economy' used by Slow Food is not so far from the sense that scholars give to this notion in other movements. Indeed it is a growing presence in scientific debates (Hart, Laville and Cattani 2010; Fassin 2009). ${ }^{21}$ The spaces of political action permitted in alternative moral economies allow a renewed commitment. Positive proposals, 'for' something - pleasure and conviviality or local economies for example - ("we are for change, we are for this or for that..." as in the case of presidia) now include the movement being 'against' something else more explicitly - whether it is industrial agriculture or GMOs.

In summary, I have argued that the Slow Food presidia integrate and synthesize the existing tension in the movement between an ideal dimension and concrete action, between economy and ecology and between market and utopia. They are a project with a strong economic as well as a political dimension. This dual character of doing economic good and being a model of political action gives them an intermediary role between the different aspects of the movement. They also allow Slow Food to define political, normative and economic spaces and to place itself 'within' the politics of food.

\section{References}

Abram, S. and J. Waldren. 1997. Introduction: tourists and tourism. Identifying with people and places. In S. Abram, J. Waldren, and V. L. Macleod (eds.) Tourists and tourism: identifying with people and places. Oxford: Berg. Pp. 1-11.

Appadurai, A. (ed.) 1988. The social life of things: commodities in cultural perspective. Cambridge: Cambridge University Press.

Appadurai, A. 1998. Modernity at large: cultural dimensions of globalisation. Minneapolis: University of Minnesota Press.

Battaglino, C., Giannini, E., Milano, S. 2010. Social report 2009. Bra: Slow Food Foundation for Biodiversity.

Battaglino, C., Ceriani, S., Giannini, E., Milano, S. 2012. Social report 2011. Bra: Slow Food Foundation for Biodiversity.

Corti, M. 2011. I ribelli del bitto. Quando una tradizione casearia diventa eversiva. Bra: Slow Food Editore.

\footnotetext{
${ }^{20}$ The attention to techniques of production that 'respect' the environment are not translated into the necessity of having an organic certification. At times, very small producers (from the economic point of view) are not in a position to obtain a certificate, and so other political reasons play a role in this choice.

${ }^{21}$ On the moral economy, see Thompson (1993). On the notion of 'human economy', see Keith Hart's Manifesto for a human economy (2013); "We urgently need to make a world where all people can live together. Small may be beautiful and a preference for initiatives grounded in local social realities is unchallengeable, but large-scale bureaucracies, whether governments or business corporations, are also essential if our aspirations for economic democracy are to embrace the movement of the world we live in." On alternative consumer movements, see Dubuisson-Quellier (2009) and Counihan and Siniscalchi (2014).
} 
Counihan, C. and V. Siniscalchi (eds.). 2014. Food activism: agency, democracy and economy. London: Bloomsbury (in press).

Dubuisson-Quellier, S. 2009. La consommation engagée. Paris: Sciences Po, les Presses.

Fassin, D. 2009. Les économies morales revisitées. Annales. Histoire, Sciences Sociales 6:1237-1266.

Fitting, E. 2011. The struggle for maize: campesinos, workers, and transgenic corn in the Mexican countryside. Durham: Duke University Press.

Grimes, K. M. 2005. Changing the rules of trade with global partnership: the fair trade movement. In J. Nash (ed.) Social movements: an anthropological reader. Oxford: Blackwell. Pp. 237-248.

Gupta, A. and J. Ferguson (eds.). 1999. Culture, power, place: explorations in critical anthropology. London: Duke University Press.

Hart, K., Laville, J.L. and A.D. Cattani (eds.). 2010. The human economy. Cambridge: Polity Press.

Hart, K. 2013. Manifesto for a human economy. http://thememorybank.co.uk/2013/01/20/object-methodsand-principles-of-human-economy/ (Retrieved 3-18-2013).

Hartog, F. 2003. Régimes d'historicité. Présentisme et expériences du temps. Paris: Seuil.

Herzfeld, M. 1997. Cultural intimacy: social poetics in the nation-state. New York and London: Routledge.

Karpik L. 2007. L'économie des singularités. Paris: Gallimard.

Koensler A. and C. Papa 2013. Introduction: beyond anthropocentrism, changing practices and the politics of 'nature.' Journal of Political Ecology 20: 286-294.

Lamine, C. 2008. Les AMAP: un nouveau pacte entre producteurs et consommateurs? Gap: Yves Michel.

Leitch, A. 2003. Slow Food and the politics of pork fat: Italian food and European identity. Ethnos 68 (4): 437-462.

Leitch, A. 2009. Slow Food and the politics of 'virtuous globalization'. In D. Inglis and D. Gimlin (eds.) The globalization of food. Oxford: Berg. Pp. 45-64.

Lien M.E. and B. Nerlich (eds.). 2004. The politics of food. Oxford: Berg.

Low, S.M. and D. Lawrence-Zùniga (eds.). 2003. The anthropology of space and place: locating culture. Oxford: Blackwell.

Luetchford, P. 2008. Fair Trade and global commodity: coffee in Costa Rica. London: Pluto Press.

Meneley, A. 2007. Like an Extra Virgin. American Anthropologist 109 (4): 678-687.

Murdoch, J. and M. Miele. 2004. A new aesthetic of food? Relational reflexivity in the 'alternative' food movement. In M.Harvey, A. McMeekin, and A. Warde (eds.) Qualities of food. Manchester: Manchester University Press. Pp. 156-175.

Nash, J. 2005. Introduction: social movements and global process. In J. Nash (ed.) Social movements: an anthropological reader. Oxford: Blackwell. Pp. 1-26.

Olivier de Sardan, J. P. 2008. La rigueur du qualitatif: les contraintes empiriques de l'interprétation socioanthropologique. Louvain-La-Neuve: Academia-Bruylant. Review

Papa, C. 2002. Il prodotto tipico come ossimoro: il caso dell'olio extravergine d'oliva umbro. In V. Siniscalchi (ed.) Frammenti di economie. Ricerche di antropologia economica in Italia. Cosenza: Luigi Pellegrini Editore. Pp. 159-191.

Parkins, W. and G. Craig 2006. Slow living. Oxford: Berg.

Paxson, H. 2010. Locating value in artisan cheese: reverse engineering terroir for new-world landscapes. American Anthropologist 112 (3): 444-457.

Petrini, C. 2005. Buono, pulito, giusto: principi di nuova gastronomia. Torino: Einaudi.

Piermattei, S. 2013. Local farmers vs. environmental universalism: conflicts over nature conservation in the Parco Nazionale dei Monti Sibillini, Italy. Journal of Political Ecology 20: 306-317.

Sassatelli, R. and F. Davolio 2010. Consumption, pleasure and politics: Slow Food and the politico-aesthetic problematization of food. Journal of Consumer Culture, 10(2): 202-232.

Schatz, E. (ed.) 2009. Political ethnography: what immersion contributes to the study of power. Chicago: The University of Chicago Press.

Siniscalchi, V. 2010. Regimi di singolarità e politiche della ripetizione. La ricerca folklorica 61: 51-61.

Siniscalchi, V. 2013. Slow versus Fast: économie et écologie dans le mouvement Slow Food. Terrain 60: 132-147.

Slow Food 1997. Manifesto dell'Arca del gusto. http://www.fondazioneslowfood.it/filemanager/arca/manifesto.pdf

Terrio, S. 2000. Crafting the culture and history of French chocolate. Berkeley: University of California Press.

Thompson, E.P. 1993. Customs in common: studies in traditional popular culture. New York: The New Press. Ulin, R.C. 1995. Invention and representation as cultural capital. American Anthropologist 97(3): 519-527. 
Ulin, R.C. 1996. Vintage and traditions: an ethnohistory of southwest French wine cooperatives. Washington: Smithsonian Institution Press.

Zerilli, F. M. 2010. The rule of soft law: an introduction. Focaal: journal of global and historical anthropology 56: 3-18.

\begin{abstract}
This article studies ways in which the Slow Food movement creates spaces for political action and elaborates new normative systems, imagining new forms of economy. Taking quality consumption and production, respect for the environment, and the rights of small producers as its core aims, this movement has today become an actor in the larger debates concerning the problematics of food, agriculture and fishing. At the same time, Slow Food is a legitimate actor in spaces of political and social contestation and applies its philosophy of a sustainable economy (represented in the triad 'good, clean and fair') globally to defend local production. Slow Food makes gastronomic diversity an element of biological and environmental diversity. This article is based on fieldwork carried out since 2006 within the French and Italy networks of the movement and in its Italian headquarters. The article analyzes the interrelations between economy, legality and environment in some Slow Food projects such as the presidia projects. Through the presidia, the movement plays an active role in the production of new norms that permit the imagination of a moral economy of food.
\end{abstract}

Keywords: Slow Food, norms, economy, typicity, food activism

\title{
Résumé
}

Cet article étudie comment le mouvement Slow Food crée d'espaces d'action politique, élabore de nouveaux systèmes normatifs en imaginant des nouvelles formes d'économie. En s'appuyant sur la définition d'une consommation et d'une production de qualité, sur le respect de l'environnement et des droits des petits producteurs, ce mouvement est devenu aujourd'hui un acteur dans les grands débats sur les problématiques de l'alimentation, de l'agriculture et de la pêche. En même temps, Slow Food est un acteur légitime dans les espaces de contestation politique et sociale. Sa philosophie d'une économie durable (représentée par la triade «bon, propre et juste») est appliquée au niveau mondial pour défendre les productions locales et l'origine des produits. La diversité gastronomique est pour Slow Food un élément de la diversité biologique et environnementale. Ce texte est basé sur le travail de terrain mené depuis 2006 dans les réseaux français et italien du mouvement et dans son quartier général en Italie. L'article analyse les interrelations entre économie, légalité et environnement dans certains projets de Slow Food, comme celui des Sentinelles. A travers les projets des Sentinelles, le mouvement joue un rôle actif dans la production de nouvelles normes qui permettent d'imaginer une économie morale de la nourriture.

Mots clés: Slow Food, normes, économie, typicité, activisme

\begin{abstract}
Questo scritto analizza i modi in cui il movimento Slow Food crea spazi di azione politica, elaborando nuovi sistemi normativi e immaginando nuove forme di economia. Partendo dalla definizione di un consumo e una produzione di qualità, dal rispetto dell'ambiente e dei diritti dei piccoli produttori, questo movimento è diventato oggi un attore nei grandi dibattiti relativi alle problematiche del cibo, dell'agricoltura e della pesca. Al tempo stesso Slow Food è un attore legittimo nei luoghi di contestazione politica e sociale. La filosofia di un'economia sostenibile (rappresentata dalla triade «buono, pulito e giusto») è applicata a livello globale per difendere le produzioni locali e l'origine dei prodotti. La diversità gastronomica è per Slow Food un elemento della diversità biologica e ambientale. Il testo si basa sul lavoro sul campo realizzato a partire dal 2006 nella rete francese e in Italia, nel quartier generale di Slow Food. L'articolo analizza i legami che esistono tra economia, legalità e ambiente, in alcuni progetti elaborati da Slow Food, come il progetto dei presidi. Attraverso di esso il movimento svolge un ruolo attivo nella produzione di nuove norme che consentono di immaginare un'economia morale del cibo.
\end{abstract}

Parole chiave: Slow Food, norme, economia, tipicità, attivismo 